\title{
Pembinaan Pengrajin Sapu ljuk di Dusun Krajan Desa Kanigoro Kecamatan Pagelaran Kabupaten Malang
}

\author{
Asroful Anam $^{1}$, Teguh Rahardjo ${ }^{1}$, Ni Putu Agustina ${ }^{2}$ \\ ${ }^{1}$ Departemen Teknik Mesin, ${ }^{2}$ Departemen Geodesi, Institut Teknologi Nasional Malang \\ Jl. Sigura-gura No.2 Malang, 65145, Indonesia
}

\section{ARTICLE INFO:}

Received: 2020-02-19 Revised: 2020-04-07

Accepted: 2020-06-18

Keywords:

Craftsmen; Kanigoro;

Palm broom

\section{ABSTRACT}

The prosperous and decent to need of both primary and secondary necessaries life are absolutely needed by every family. So they endeavor to increase their abilities to obtain subsist prosperity by entrepreneurship, as handicraft businesses, palm broom, that made by people in Krajan Hamlet, Kanigoro Village, Pagelaran District, Malang Regency. But for reaching the independent business, they meet many obstacles, such as producted quality lower than factory production; low market opportunities, and business governance out of standardized. Constraints faced by palm broom craftsmen in Krajan Hamlet, Kanigoro Village, occur without guidance and attention from the government. So that we as academics/lecturers take the initiative to foster the broom fibers craftsmen through the Community Service Program in order to improve the quality of their products, penetrate the wider market, and home industry management with good governance. This Community Service method used completely ongoing coaching. Based on the results of that implementation, the product can compete with the factory product broom; an increase in the market, and an increase in the welfare of the craftsman family. By this, creating a good governance management of home industry, and making young adults interest to maintain the palm broom.

(C) 2020 Published by University of Merdeka Malang. This is an open access article distributed under the CC BY-SA 4.0 license (https://creativecommons.org/licenses/by-sa/4.0/)

How to cite: Anam, A., Rahardjo, T., \& Agustina, N. P. (2020). Pembinaan Pengrajin Sapu ljuk di Dusun Krajan Desa Kanigoro Kecamatan Pagelaran Kabupaten Malang. Abdimas: Jurnal Pengabdian Masyarakat Universitas Merdeka Malang, 5(2), 159-167. https://doi.org/10.26905/abdimas.v5i2.4000

\section{PENDAHULUAN}

Desa Kanigoro adalah salah satu desa yang ada di Kecamatan Pagelaran yang merupakan kecamatan baru yang ada di Kabupaten Malang. Kecamatan Pagelaran dulunya adalah Desa Pagelaran bagian dari wilayah Kecamatan Gondanglegi, yang pada tahun 1990an desa tersebut menjadi kecamatan akibat terjadi pemekaran wilayah kecamatan yang ada di Kabupaten Malang dengan 13 desa di bawah pemerintahannya. Kecamatan Pagelaran dan umumnya Kabupaten Malang seperti kota atau kabupaten lain di Indonesia pada umumnya baru tumbuh dan berkembang setelah hadirnya pemerintah kolonial Belanda. Fasilitas umum direncanakan sedemikian rupa agar memenuhi kebutuhan keluarga Belanda. Kesan diskriminatif itu 
ABDIMAS: Jurnal Pengabdian Masyarakat Universitas Merdeka Malang

Volume 5, No 2, Juli 2020: 159-167

masih berbekas hingga sekarang. Misalnya Ijen Boulevard kawasan sekitarnya. hanya dinikmati oleh keluargakeluarga Belanda dan Bangsa Eropa lainnya, sementara penduduk pribumi harus puas bertempat tinggal di pinggiran kota dengan fasilitas yang kurang memadai. Kawasan perumahan itu sekarang bagai monumen yang menyimpan misteri dan seringkali mengundang keluarga-keluarga Belanda yang pernah bermukim di sana untuk bernostalgia.

Sehubungan dengan dukungan dalam pelaksanaan pembangunan di Kabupaten Malang, ITN Malang yang juga merupakan perguruan tinggi yang berkedudukan di wilayah Kota Malang berperan aktif dalam pembangunan tersebut sesuai dengan fungsinya yaitu sebagai lembaga pendidikan dan pengembangan ipteks, salah satunya adalah program pengabdian masyarakat (Abdimas) tugas pokok bagi dosennya dalam mendukung program pembangunan pemerintah dalam proses pemberdayaan pembangunan berupa program-program yang mendukung penyegaran hidup gotong royong, mampu memberikan tambahan bekal ilmu pengetahuan dan ketrampilan serta mendorong dalam pemantapan fungsi-fungsi keluarga khususnya di wilayah Kabupaten Malang.

Konsep pemberdayaan yaitu suatu proses dimana masyarakat (khususnya bagi masyarakatmasyarakat yang kurang akses pada sumber-sumber daya pembangunan) harus didorong untuk meningkatkan kemandiriannya dalam mengembangkan peri kehidupan mereka. Hal tersebut sejalan dengan yang disampaikan oleh Fathy (2019) bahwa modal sosial diasumsikan sebagai alternatif bentuk modalitas lain. Secara teoritis ada perdebatan mengenai modal sosial bermuara kepada relasi-relasi sosial. Perdebatan itu berkenaan dengan konseptualisasi modal sosial sebagai kapital konkrit dimana individu atau kelompok mampu mendayagunakan relasi-relasi sosial mencakup nilai-norma, jaringan sosial dan kepercayaan untuk memperoleh keuntungan ekonomi dan manfaat sosial. Sehingga dalam melaksanakan Program Pengabdian Masyarakat, kegiatan disesuaikan dengan kemampuan masyarakat dan anggotanya sehingga pelaksanaan kegiatan itu bisa dilakukan oleh, dari dan untuk keluarga, dan masyarakat setempat. Dengan pengertian lain, kegiatan dilaksanakan atas kemampuan dan swadaya masyarakat sebagai upaya memberdayakan keluarga sejahtera dan membangun kesejahteraan rakyat secara luas (Utami, 2017).

Wirausahawan/pengrajin di bidang produksi sapu ijuk yang ada di Dusun Krajan Desa Kanigoro Kecamatan Pagelaran Kabupaten Malang sama halnya dengan wirausaha-wirausaha lain, mereka ingin apa yang mereka tekuni dapat menghasilkan rupiah yang cukup untuk memenuhi kebutuhan hidup keluarganya. Tetapi hal tersebut sulit dilakukan karena beberapa hal, semisal kurang bersaingnya produk sapu ijuk mereka dengan produk sapu ijuk buatan pabrik yang lebih moderen. Tidak hanya itu, dalam memasarkan produknya, pengrajin sapu ijuk di Desa Kanigoro menghadapi kesulitan menembus pasar di perkotaan. Padahal produk yang dihasilkan oleh salah satu desa di Kecamatan Pagelaran Kabupaten Malang lebih murah dan tahan lama jika dibandingkan dengan produk pabrikan.

Kendala-kendala yang dihadapi pengrajin-pengrajin sapu ijuk di Dusun Krajan Desa Kanigoro Kecamatan Pagelaran Kabupaten Malang adalah pembuatan sapu ijuk masih dilakukan secara tradisional, mulai dari pembuatan tongkat sapu, tali sapu, dan proses penjahitan dan finishing produk juga dilakukan secara manual dan tradisional, seperti tampak pada Gambar 1 dan 2. Hal tersebut tanpa mendapatkan perhatian dari pemerintah desa maupun pemerintah diatasnya untuk membina dan menumbuh kembangkan produk-produk sapu ijuk yang dapat menjadi produk andalan desa, kecamatan atau kabupaten melalui program pembinaan atau pemberdayaan pengrajin (Sarno, 2018; Suwahno, 2017). Sehingga produk sapu ijuk tersebut dapat bersaing di pasaran, terutama di pasar perkotaan di tingkat lokal maupun nasional 


\section{Pembinaan Pengrajin Sapu ljuk di Dusun Krajan Desa Kanigoro Kecamatan Pagelaran Kabupaten Malang}

Asroful Anam ${ }^{1}$, Teguh Rahardjo ${ }^{1}$, Ni Putu Agustina ${ }^{2}$

untuk memperbaiki derajat kesejahteraan keluarga dan masyarakat luas (Lubis M.M., et al., 2016), terutama di Desa Kanigoro yang menekuni kerajinan pembuatan sapu ijuk dari pohon aren.
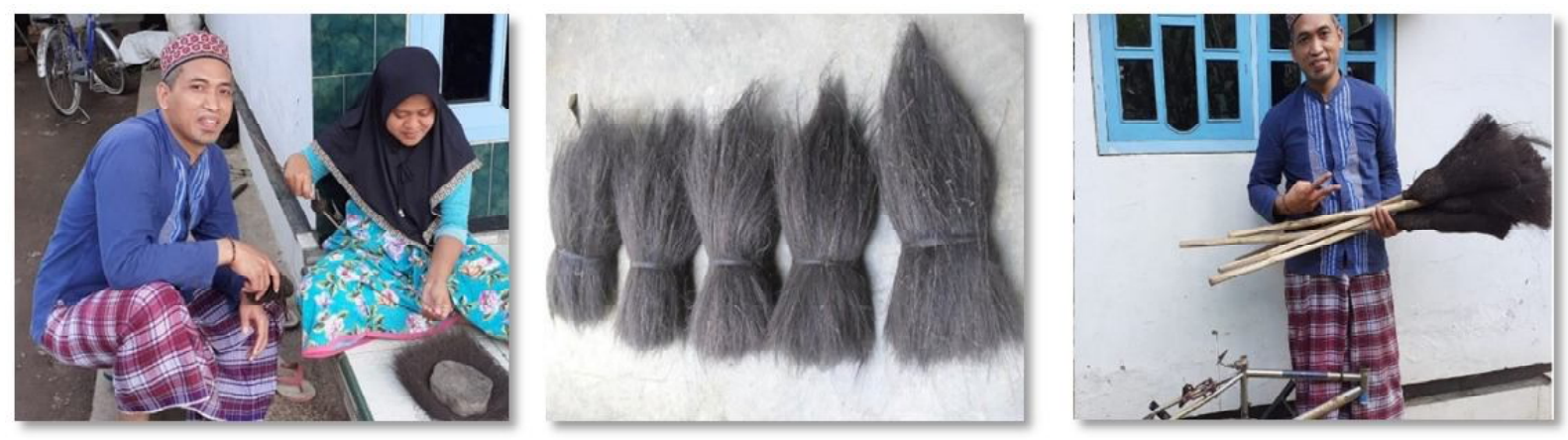

Gambar 1. Pembuatan sapuk dan tali ijuk manual

Kurangnya perhatian pemerintah desa atau pemerintahan diatasnya di tingkat kabupaten dilatarbelakangi oleh berbagai aspek kehidupan, semisal kurangnya komunikasi antara masyarakat dengan pemangku kebijakan terkait perkembangan penduduk, kemajuan ilmu pengetahuan dan teknologi, dinamika kegiatan ekonomi, perkembangan/perluasan jaringan komunikasi-transportasi dan sebagainya. Faktorfaktor tersebut akan membawa perubahan terhadap bentuk keruangan di wilayah yang bersangkutan, baik secara fisik maupun non fisik, sebagai wadah kegiatan manusia di dalamnya.

Desa Kanigoro memiliki permasalahan-permasalahan hampir sama dengan desa-desa yang lain di kecamatan-kecamatan di wilayah Kabupaten Malang, mulai tingkat RT dan RW juga mempunyai permasalahan yang sama. Sehingga untuk mendukung pelaksanaan pembangunan Kabupaten Malang, Institut Teknologi Nasional Malang melalui program pengabdian kepada masyarakat yang harus di penuhi oleh tenaga pendidiknya selalu aktif berpartisipasi dalam program pembangunan nasional, salah satu di Dusun Krajan Desa Kanigoro Kecamatan Pagelaran Kabupaten Malang dengan fokus pada pembinaan pada pengrajin sapu ijuk (Fitrawaty et al., 2018), agar produknya dapat bersaing dengan produk sapu ijuk buatan pabrik yang lebih moderan; dapat menembus pasar di perkotaan baik tingkat lokal maupun nasional; dan memiliki manajemen home industri yang handal dalam bertahan dalam persaingan-persaingan dengan produk pabrikan.

Tipologi Desa Kanigoro antara lain: persawahan, perladangan, perkebunan, peternakan, nelayan, pertambangan galian, kerajinan dan industri kecil, industri sedang dan besar serta jasa perdagangan. Luas wilayah Kelurahan Bakalan Krajan adalah 197,450 km2, dimana sekitar kurang lebih 40\% atau sekitar $78,98 \mathrm{~km} 2$ berupa lahan sawah, selebihnya terdiri lahan tegalan dan perumahan. Sedangkan topografi wilayah Desa Kanigoro Kecamatan Pagelaran Kabupaten Malang adalah berupa dataran tinggi dan tanah datar. Tercatat orbitasi kelurahan terletak pada dataran rendah yang berjarak sekitar $7 \mathrm{Km}$ dari pusat pemerintah Kecamatan Pagelaran dan pusat pemerintahan Kabupaten Malang, berjarak $28 \mathrm{Km}$ dari pusat pemerintahan Kota Malang, dan dan berjarak $118 \mathrm{Km}$ dari Ibukota Provinsi Jawa Timur. Penduduk Desa Kanigoro berjumlah sekitar 8.500 jiwa dengan jumlah kepala keluarga sekitar 2.500 jiwa dan anggota keluarga terdiri atas laki-laki sekitar 2.700 Jiwa, dan perempuan 3.200 Jiwa. Dilihat dari jenis pekerjaan sebagian besar adalah petani, dan sebagai kecil pedagang, guru, dan TNI/POLRI. 


\section{ABDIMAS: Jurnal Pengabdian Masyarakat Universitas Merdeka Malang}

Volume 5, No 2, Juli 2020: 159-167

Berdasarkan jumlah penduduk di Desa Kanigoro Kecamatan Pagelaran Kabupaten Malang, sumber daya manusia ditinjau dari tingkat pendidikan masyarakat lulusan sekolah dasar sederajat sekitar 1.000 orang, Lulusan SMP sederajat 1.500 orang, Lulusan SMU sederajat sekitar 2.000 orang, lulusan Akademi/ D1-D3 sekitar 150 orang, lulusan sarjana sekitar 300 orang, dan sisanya pendidikan pondok pesantren. Sedangkan katagori Masyarakat miskin sekitar 1.500 kepala keluarga, saat ini bidang usaha yang dikerjakan oleh warga antara lain: pabrik tahu, pengelasan, bengkel kendaraan, peternakan bebek, peternakan lele, pembuatan tempe kacang, pembuatan tempe kedelai, dan usaha pengrajin sapu ijuk yang sedang mengalami penurunan produktifitas.

Berdasarkan hasil penelusuran dilapangan terhadap permasalahan dan potensi di wilayah Kabupaten Malang yang dilaksanakan oleh Tim LPPM - ITN Malang teridentifikasi masalah dan potensi meliputi: (1) Masih tingginya angka kemiskinan. (2) Masih rendahnya pengetahuan masyarakat dalam pengelolaan potensi wilayahnya. (3) Semakin berkurangnya lahan terbuka hijau. (4) Potensi yang ada di masyarakat belum terkelola dengan baik. (5) Belum maksimalnya penyebaran informasi terhadap program pembangunan dan bantuan bagi masyarakat.

Sedangkan potensi yang ada di masyarakat di wilayah Kabupaten Malang meliputi: (1) Motivasi dan kreativitas masyarakat yang mendukung. (2) Tersedianya lahan tidur di pemukiman masyarakat dan fasilitas umum seperti masjid, sekolah, perkantoran, balai desa, lapangan olahraga dan taman-taman kota. (3) Belum beragamnya hasil-hasil indutri kecil menengah dan industri rumah tangga. (4) Tersedianya alat-alat teknologi tepat guna bagi masyarakat.

Untuk Tingkat pengangguran di Desa Kanigoro Kecamatan Pagelaran Kabupaten Malang masih tinggi dan minimnya ketersediaan lapangan pekerjaan juga merupakan masalah bagi masyarakat di Desa Kanigoro, beberapa adalah: (1) Sebagian besar masyarakat di Desa Kanigoro adalah petani. (2) Minat dan motivasi masyarakat dalam mempertahankan kerajinan tangan khususnya wirausaha pada sapu ijuk sangat rendah. (3) Belum beragamnya usaha kecil di bidang industri rumah tangga. (4) Mayoritas masyarakat mempunyai mata pencaharian dari hasil perdagangan, pertanian, perikanan air tawar dan buruh pekerja.

Dari berbagai permasalahan yang ada di Desa Kanigoro Kecamatan Pagelaran Kabupaten Malang, secara garis besar ada dua pokok, yang pertama adalah muncul akibat pengelolaan proses kerajinan tangan yang belum optimal, dan yang kedua adalah kurangnya minat masyarakat untuk berwirausaha, khususnya mempertahankan kerajinan-kerajinan tangan yang diwarisi secara turun temurun dan menjanjikan nilai rupiah yang tinggi apabila dilakukan secara tekun dan disiplin. Sehingga, permasalahan yang ada perlu dipikirkan jalan keluar untuk meningkatkan tarap hidup masyarakat di Desa Kanigoro Kecamatan Pagelaran Kabupaten Malang yang mandiri dan sejahtera dalam penghidupan, semisal melalui pembinaan atau pemberdayaan.

Tujuan pelaksanaan program Abdimas dirumuskan bersama antara Kepala Desa dan pengrajin sapu ijuk serta masyarakat lain yang ada di Desa Kanigoro Kecamatan Pagelaran Kabupaten Malang dengan Tim dosen Program Pengabdian Masyarakat Institut Teknologi Nasional Malang di desa tersebut (Asroful Anam, ST., MT; Ir. Teguh Rahardjo, MT., dan Ir. Ni Putu Agustini, MT) sebagai solusi atas permasalahan yang di hadapi pengrajin sapu ijuk Desa Kanigoro terdapat beberapa tujuan pelaksanaan program pengabdian masyarakat, yaitu meliputi: meningkatkan produktifitas sapu ijuk yang dapat bersaing dengan sapu produk pabrik, meningkatkan pemasaran sapu ijuk di pasar perkotaan baik tingkat lokal maupun nasional, meningkat manajemen tata kelola home industri di bidang sapu ijuk yang handal dan berkelanjutan. 


\section{Pembinaan Pengrajin Sapu ljuk di Dusun Krajan Desa Kanigoro Kecamatan Pagelaran Kabupaten Malang}

Asroful Anam ${ }^{1}$, Teguh Rahardjo ${ }^{1}$, Ni Putu Agustina ${ }^{2}$

Dan meningkatkan minat pemuda untuk mempertahankan kerajinan pembuatan sapu ijuk yang memiliki nilai ekonomi tinggi,

Sebagai langkah awal pada pelaksanaan program pengabdian masyarakat di Desa Kanigoro Kecamatan Pagelaran Kabupaten Malang telah dibentuk dua kelompok unit usaha dibidang kerajinan sapuk ijuk, yaitu: (1) Kelompok pembuatan sapu ijuk, dan (2) Kelompok manajemen dan pemasaran sapu ijuk.

Unit pembuatan sapu ijuk menjadi wadah dan pusat bimbingan konseling dan konsultasi terkait permasalahan-permasalahan yang dihadapi pengrajin sapu ijuk beserta solusi-solusi terkait, sehingga produktifitas sapu ijuk yang dapat bersaing dengan sapu produk pabrik. Sedangkan untuk unit kelompok manajemen dan pemasaran sapu ijuk berkonsentrasi pendampingan dan evaluasi secara bersama-sama pada proses menembus pasar dengan tujuan terbukanya pangsa pasar sapu ijuk di perkotaan baik tingkat lokal maupun nasional.

Hidup yang sejahtera adalah dambaan setiap keluarga yang hidup di muka bumi (Carolina, 2017). Sehingga mempunyai pendapatan yang layak dan dapat memenuhi seluruh kebutuhan baik primer maupun sekunder mutlak di perlukan oleh setiap keluarga. Mulai dari petani, pedagang, buruh maupun wirausahawan, mereka berupaya agar apa yang mereka perjuangkan dapat bertahan dan bisa meningkatkan produktifitas, dengan harapan penghidupan yang sejahtera dan mandiri dapat di rasakan seluruh anggota keluarga bahkan juga dapat dirasakan oleh masyarakat sekitar (Marnisah et al., 2018). Sebagai contoh wirausahawan/ pengrajin di bidang produksi sapu ijuk yang ada di Dusun Krajan Desa Kanigoro. Sebagai pengrajin sapu tradisional dari serat pohon aren, mereka ingin apa yang mereka tekuni dapat menghasilkan rupiah yang cukup untuk memenuhi kebutuhan hidup keluarganya. Tetapi hal tersebut sulit di lakukan karena beberapa hal, semisal kurang bersaingnya produk sapu ijuk mereka dengan produk sapu ijuk buatan pabrik yang lebih moderan. Tidak hanya itu, dalam memasarkan produknya, pengrajin sapu ijuk di Desa Kanigoro menghadapi kesulitan menembus pasar di perkotaan. Padahal produk yang dihasilkan oleh salah satu desa di Kecamatan Pagelaran Kabupaten Malang lebih murah dan tahan lama jika dibandingkan dengan produk pabrikan.

Dalam proses pembuatan sapu ijuk di Desa Kanigoro Kecamatan Pagelaran Kabupaten Malang masih dilakukan secara tradisional, mulai dari pembuatan tongkat sapu, tali sapu, dan proses penjahitan dan finishing produk juga dilakukan secara manual dan tradisional. Muzakkir \& Rochgiyanti (2012) menyatakan hubungan kerja pengajin sapu ijuk juga bisa bersifat interaktif dengan pengumpul. Pengrajin sapu ijuk dengan keahliannya akan menyerahkan hasil karyanya kepada pengumpul dengan disertai imbal jasa atau upah. Kendala-kendala yang dihadapi pengrajin-pengrajin sapu ijuk di Desa Kanigoro merupakan fenomena yang terjadi secara turun temurun tanpa adanya perhatian dari pemerintah desa maupun pemerintah diatasnya untuk membina dan menumbuhkan kembangkan produk-produk sapu ijuk yang dapat menjadi produk andalan desa, kecamatan atau kabupaten. Sehingga produk sapu ijuk tersebut dapat bersaing di pasaran, terutama di pasar perkotaan di tingkat lokal maupun nasional untuk memperbaiki derajat kesejahteraan keluarga dan masyarakat di Desa Kanigoro yang menekuni kerajinan pembuatan sapu ijuk dari pohon aren.

Pembuatan, pemasaran, dan manajemen industri rumahan sapu ijuk di Desa Kanigoro mengundang perhatian kami sebagai akademisi/dosen yang yang mempunyai tugas pokok salah satunya di bidang pengabdian masyarakat. Sebagai tugas pokok di bidang tersebut kami kelompok dosen ITN Malang 
ABDIMAS: Jurnal Pengabdian Masyarakat Universitas Merdeka Malang

Volume 5, No 2, Juli 2020: 159-167

terpanggil untuk membina pengrajin-pengrajin sapu ijuk agar dapat meningkatkan nilai produktifitas, pemasaran, dan manajemen home industrinya guna bersaing dengan produk-produk sapu ijuk yang di buat pabrikan secara modern. Pada program pengabdian masyarakat (Abdimas), ITN Malang merupakan wahana pemberdayaan 8 fungsi keluarga secara terpadu, utamanya fungsi agama atau keTuhanan yang Maha Esa, fungsi cinta kasih, fungsi perlindungan, fungsi reproduksi dan kesehatan, fungsi pendidikan, fungsi sosial budaya, fungsi ekonomi atau wirausaha dan fungsi lingkungan. Kegiatan abdimas adalah forum silaturahmi, advokasi, komunikasi, informasi, edukasi dan sekaligus bisa dikembangkan menjadi wadah koordinasi kegiatan penguatan fungsi-fungsi keluarga secara terpadu. Dalam hal-hal tertentu bisa juga menjadi wadah pelayanan keluarga secara terpadu, yaitu pelayanan pengembangan keluarga secara berkelanjutan, dalam berbagai bidang, utamanya agama, pendidikan, kesehatan, wirausaha dan lingkungan hidup, sehingga keluarga secara harmonis bisa tumbuh mandiri dan sejahtera (Kasman, 2018).

\section{METODE}

Pada proses pendekatan yang dilakukan oleh tim pelaksana pada pelaksanaan Program Pengabdian Masyarakat Institut Teknologi Nasional Malang di Desa Kanigoro Kecamatan, Kabupaten Malang di dasarkan pada metode pendekatan sosial interaktif, yaitu berupa survei dan studi lapangan yang dilakukan team pelaksana serta hasil beberapa kunjungan terkait permasalahan-permasalahan yang dihadapi masyarakat, terutama kelompok masyarakat yang yang menjalani usaha rumahan semisal pengrajin sapu ijuk. Proses pendekatan dilakukan melalui beberapa forum interaktif di kantor desa dan rumah kelompok pengrajin sapu ijuk. Sehingga di temui banyak kesamaan pandangan dan rasa saling melengkapi satu sama lain, bersahabat, dan nyaman. Pada forum interaktif baik formal maupun non formal banyak didapati hal-hal positif, tidak hanya berguna bagi masyarakat sekitar bahkan juga menambah wawasan dan hal baru yang belum di ketahui oleh tim pelaksana Program pengabdian masyarakat Institut Teknologi Nasional Malang dengan mengkaitkan keadaan lingkungan sekitar yang mungkin dapat mendongkrak kehidupan yang lebih baik.

Gambaran pelaksanaan program abdimas yang kami lakukan di Dusun Krajan Desa Kanigoro Kecamatan Pagelaran Kabupaten Malang ditunjukkan pada Gambar 1.

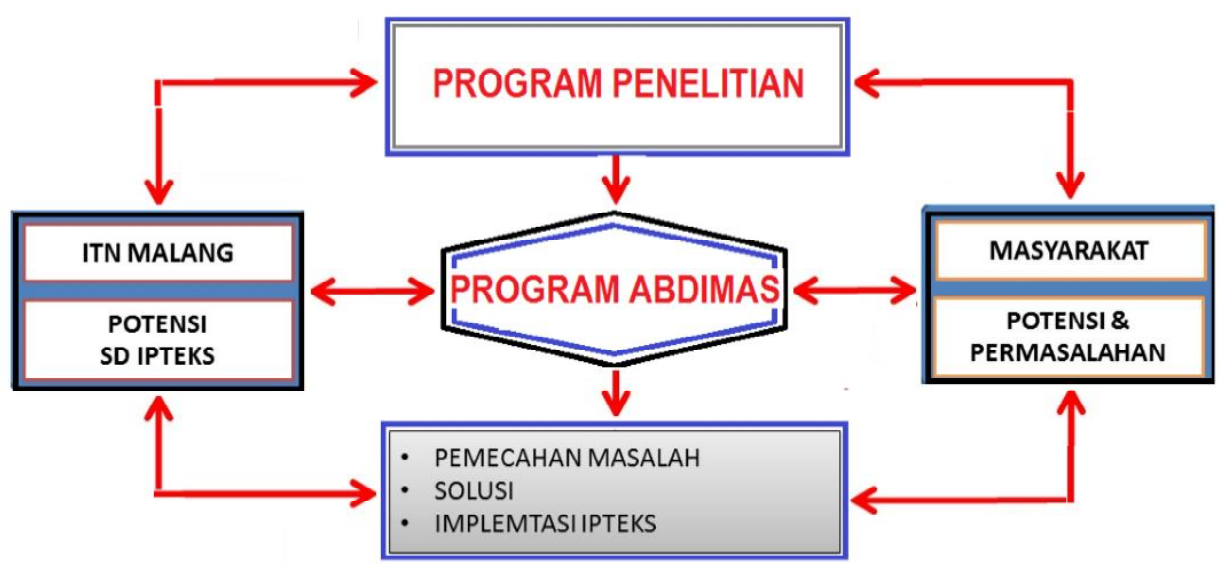

Gambar 2. Gambaran pelaksanan Program Abdimas 


\section{Pembinaan Pengrajin Sapu ljuk di Dusun Krajan Desa Kanigoro Kecamatan Pagelaran Kabupaten Malang \\ Asroful Anam¹, Teguh Rahardjo ${ }^{1}$, Ni Putu Agustina ${ }^{2}$}

Beberapa solusi untuk memecahkan permasalahan pengrajin sapu ijuk dan pemuda serta masyarakat di Desa Kanigoro Kecamatan Pagelaran Malang oleh team pelaksana kegiatan Program Pengabdian Masyarakat Institut Teknologi Nasional Malang ini adalah: (1) Alat pembuat benang ijuk dan demonstrasi penggunaan alat pembuat benang ijuk. (2) Memberikan bimbingan konseling dan konsultasi terkait permasalahan-permasalahan yang dihadapi kelompok unit pembuatan sapu ijuk beserta solusi-solusi terkait tentang bagaimana meningkatkan produktifitas sapu ijuk yang dapat bersaing dengan sapu produk pabrik. (3) Memberikan pendampingan dan evaluasi secara bersama-sama pada proses studi kelayakan pasar dan memperluas pasar yang di hadapi kelompok manajemen dan pemasaran sapu ijuk yang berfokus pada bagaimana meningkatkan pemasaran sapu ijuk di pasar perkotaan baik tingkat lokal maupun nasional. (4) Memberikan bimbingan konseling dan pendampingan manajemen operasional pada kelompok manajemen dan pemasaran sapu ijuk yang konsentrasi pada bagaiman meningkatkan tata kelola operasional manajemen home industri di bidang sapu ijuk yang handal dan berkelanjutan. (5) Berikan bimbingan konseling pada pemuda-pemuda yang difokuskan bagaimana meningkatkan minat pemuda untuk mempertahankan kerajinan pembuatan sapu ijuk yang memiliki nilai ekonomi tinggi, handal, murah, dan awet pemakaian, serta menjadi ikon kerajinan kebanggaan pemerintah desa, kecamatan, dan kabupaten.

\section{HASIL DAN PEMBAHASAN}

Langkah- langkah konsep untuk solusi atas permasalahan yang telah disepakati bersama antar unit kelompok dengan tim pelaksana kegiatan Program Pengabdian Masyarakat Institut Teknologi Nasional Malang di Desa Kanigoro Kecamatan Kabupaten Malang dihadapan kepala desa adalah sebagai berikut: (1) Bimbingan konseling dan konsultasi terkait permasalahan-permasalahan yang dihadapi pengrajin sapu ijuk beserta solusi-solusi terkait. Pada bimbingan konseling konsultasi ini di titik beratkan pada bagaimana meningkatkan produktifitas sapu ijuk yang dapat bersaing dengan sapu produk pabrik. (2) Pendampingan dan evaluasi secara bersama-sama pada proses menembus pasar. Pada pendampingan ini di titik beratkan pada bagaimana meningkatkan pemasaran sapu ijuk di pasar perkotaan baik tingkat lokal maupun nasional. (3) Bimbingan konseling dan pendampingan manajemen operasional. Pada kegiatan ini di titik beratkan pada bagaiman meningkatkan tata kelola operasional manajemen home industri di bidang sapu ijuk yang handal dan berkelanjutan. (4) Kopi darat. Pada kegiatan ini di fokuskan bagaimana meningkatkan minat pemuda untuk mempertahankan kerajinan pembuatan sapu ijuk yang memiliki nilai ekonomi tinggi, handal, murah, dan awet pemakaian, serta menjadi ikon kerajinan kebanggaan pemerintah desa, kecamatan, dan kabupaten.

Pada pelaksanaan kegiatan program pengabdian masyarakat di Desa Kanigoro Kecamatan Kabupaten Malang diharapkan seluruh mitra yang tergabung dalam dua kelompok unit usaha di bidang kerajinan sapuk ijuk, yaitu kelompok pembuatan sapu ijuk, dan kelompok manajemen dan pemasaran sapu ijuk, serta seluruh pemuda masyarakat sekitar dapat secara intensif dan disiplin mengikuti seluruh kegiatan yang yang telah disepakati, agar hal-hal yang menjadi permasalahan pengrajin sapu ijuk di Desa Kanigoro dapat teratasi dengan baik dan dapat menjadi sumbangsih ekonomi yang berkelanjutan, demi kehidupan yang lebih mandiri dan sejahtera. Untuk itu segala hal yang berkaitan dengan pelaksaan program pengabdian masyarakat di Desa Kanigoro, diharapkan masyakat yang terlibat secara bersama-sama dengan tim dapat menyediakan keperluan operasional agar kegiatan dapat berjalan dengan sukses sesuai harapan, meliputi: akomodasi (konsumsi) selama berlangsungnya kegiatan program abdimas LPPM ITN 
ABDIMAS: Jurnal Pengabdian Masyarakat Universitas Merdeka Malang Volume 5, No 2, Juli 2020: 159-167

Malang, bahan baku sapu ijuk, tempat dan peralatan bantu untuk bimbingan konseling dan konsultasi, beberapa tenaga untuk membantu penyediaan bahan baku, pembukuan dan operator produksi, promosi pemasaran, dan whiteboard untuk jadwal kegiatan bimbingan konseling, konsultasi, dan perluasan pasar sapu ijuk.
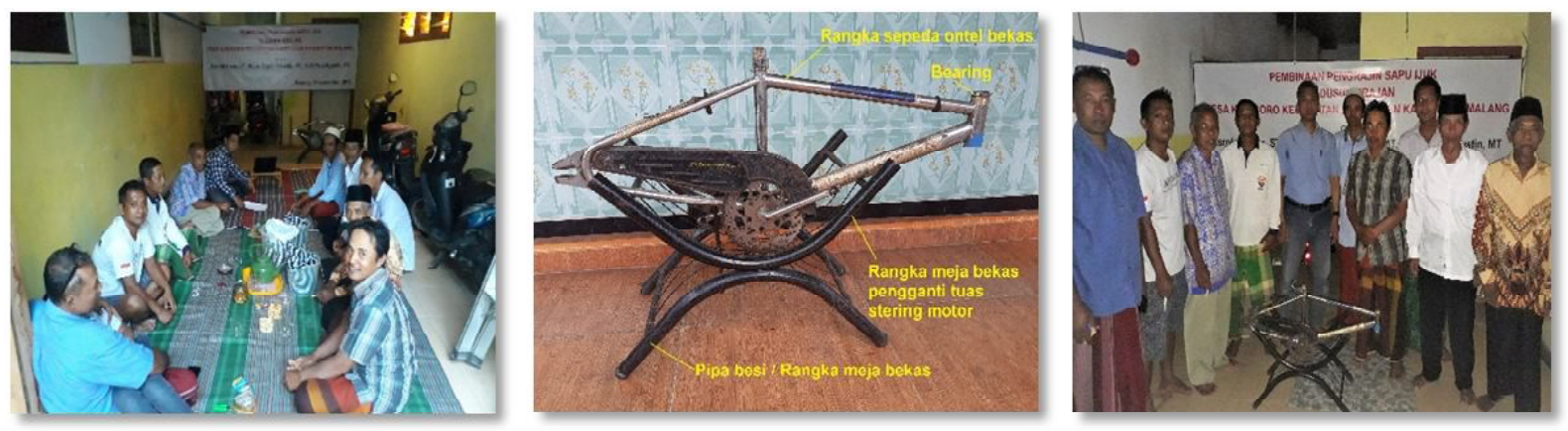

Gambar 3. Kegiatan sosialisasi alat pembuat benang ijuk

Berdasarkan data, evaluasi, dan beberapa hal hasil pembinaan tuntas pada pelaksanaan program pengabdian masyarakat di Desa Kanigoro Kecamatan Kabupaten Malang, masyarakat yang tergabung pada kelompok pengrajin atau wirausaha sapu ijuk dapat mengatasi dan menyelesaikan permasalahanpermasalahan yang dihadapi. Dampak tersebut diukur dengan terwujudnya produktifitas sapu ijuk yang dapat bersaing dengan sapu produk pabrik; adanya meningkatkan pemasaran sapu ijuk di pasar perkotaan baik tingkat lokal maupun nasional; terciptanya manajemen tata kelola home industri di bidang sapu ijuk yang handal dan berkelanjutan; dan terciptanya minat pemuda untuk mempertahankan kerajinan pembuatan sapu ijuk yang memiliki nilai ekonomi tinggi.

Setelah pelaksanaan program Abdimas dan dilakukan evaluasi, ternyata apa yang menjadi permasalahan-permasalahan masyarakat pengrajin sapu ijuk Desa Kanigoro dapat teratasi, yaitu: (1) adanya peningkatkan produktifitas sapu ijuk yang dapat bersaing dengan sapu produk pabrik; (2) adanya meningkatkan pemasaran sapu ijuk di pasar perkotaan baik tingkat lokal maupun nasional; (3) adanya peningkatan manajemen tata kelola home industry di bidang sapu ijuk yang handal dan berkelanjutan.

Dari hasil pelaksanaan program pengabdian masyarakat di Desa Kanigoro Kecamatan Kabupaten Malang dengan metode pembinaan tuntas, menunjukkan bahwa terwujud peningkatan produktifitas sapu ijuk yang dapat bersaing dengan sapu produk pabrik. Peningkatan tersebut seiring dengan adanya peluang yang lebih luas dalam peningkatan pemasaran sapu ijuk di pasar perkotaan baik tingkat lokal maupun nasional. Didukung oleh pembinaan secara berkesinambungan dalam hal manajemen tata kelola home industri yang baik, telah tercipta suasana kerja dan dampak positif bagi masyarakat, sehingga hal ini menarik minat pemuda untuk mempertahankan kerajinan pembuatan sapu ijuk yang memiliki nilai ekonomi tinggi.

\section{SIMPULAN DAN SARAN}

\section{Simpulan}

Setelah pelaksanan Program Pengabdian Masyarakat Institut Teknologi Nasional Malang akan membantu kelompok pengrajin atau wirausaha sapu ijuk dengan membuat kelompok unit usaha untuk 


\section{Pembinaan Pengrajin Sapu ljuk di Dusun Krajan Desa Kanigoro Kecamatan Pagelaran Kabupaten Malang}

Asroful Anam¹, Teguh Rahardjo ${ }^{1}$, Ni Putu Agustina ${ }^{2}$

menyelesaikan permasalahan-permasalahannya, dilakukan evaluasi dan analisa, ternyata apa yang menjadi permasalahan-permasalahan masyarakat pengrajin sapu ijuk Desa Kanigoro dapat teratasi, yaitu: produktifitas sapu ijuk yang dapat bersaing dengan sapu produk pabrik, adanya meningkatkan pemasaran sapu ijuk di pasar perkotaan baik tingkat lokal maupun nasional, terciptanya manajemen tata kelola home industri di bidang sapu ijuk yang handal dan berkelanjutan, dan terwujudnya minat pemuda untuk mempertahankan kerajinan pembuatan sapu ijuk yang memiliki nilai ekonomi tinggi.

\section{Saran}

Saran-saran untuk pelaksana Program Pengabdian Masyarakat Institut Teknologi Nasional Malang berikutnya atau para institusi lain adalah perlu adanya program pengabdian masyarakat yang fokus bahan baku lain yang dapat menggantikan ijuk, akan tetapi sasarannya tetap bagi pelaku industri kecil atau pengrajin yang ada di desa atau masyarakat pedesaan dan pegunungan karena tujuan utama dari program pengabdian masyarakat ini adalah membantu dan membina secara berkelanjutan masyarakat agar kehidupan keluarga lebih sejahtera.

\section{DAFTAR PUSTAKA}

Carolina, R. (2017). Perspektif modernisasi menuju terwujudnya keluarga sejahtera. Jurnal Keluarga Sehat Sejahtera, 15(2), 65-75. https://doi.org/10.24114/jkss.v15i2.8776

Fathy, R. (2019). Modal sosial: Konsep, inklusivitas, dan pemberdayaan masyarakat. Jurnal Pemikiran Sosiologi, 6(1), 1-17. https://doi.org/10.22146/jps.v6i1.47463

Utami B. C. (2017). Strategi pengoptimalan pencapaian program upaya peningkatan pendapatan keluarga sejahtera pada direktorat pemberdayaan ekonomi keluarga Badan Kependudukan dan Keluarga Berencana Nasional. Jurnal Niara Sejahtera, 9(2), 23-42. https://doi.org/10.31227/osf.io/be32q

Suwahno, R. D. (2017). Pemberdayaan perajin sapu ijuk di Kota Semarang. Rekayasa, 15(2), 132-138.

Lubis, M. M., Saleh, K., \& Fatmawaty. (2016). Strategi pengembangan usaha berdasarkan analisis lingkungan usaha pada industri sapu ijuk Desa Medan Sinembah Kecamatan Tanjung Morawa. Jurnal Pengabdian Kepada Masyarakat, 22(4), 67-73.

Fitrawaty, Rambe, A., Sirnulingga, K., \& Kartono, G. (2018). Pembinaan kelompok masyarakat pengrajin bordir Desa Mangga II dengan pendekatan pelatihan dan pendampingan. Jurnal Vokasi, 2(2), 75-78. https://doi.org/10.30811/vokasi.v2i2.689

Marnisah, L., Romli, H., Jenahar, T. J., \& Effendi, R. (2018). Upaya meningkatkan pendapatan rumah tangga petani karet. Jurnal Abdimas Mandiri, 1(1), 19-25. https://doi.org/10.36982/jam.v1i1.285

Muzakkir, A., \& Rochgiyanti. (2012). Perempuan pekerja dalam hubungan patron klien: Kasus pengrajin sapu ijuk di Desa Barikin. Kafa'ah: Journal of Gender Studies, 2(2), 178-198. https://doi.org/ 10.15548/jk.v2i2.61

Kasman, R. (2018). Memberdayakan masyarakat dalam meningkatkan kualitas hidup melalui bidang pendidikan, lingkungan, ekonomi dan kesehatan. Jurnal Abdimas, 2(2), 196-204.

Sarno. (2018). Pemberdayaan kelompok masyarakat perajin bambu di Desa Sirkandi Purwareja Klampok Banjarnegara. Jurnal Pengabdian dan Pemberdayaan Masyarakat, 2(2), 309. https://doi.org/ 10.30595/jppm.v2i2.2395 